\title{
NOS LABIRINTOS DE UMA GEOGRAFIA ANTI-HISTÓRICA TRUMAN, O SHOW DA VIDA**
}

\author{
Sérgio Martins*
}

\section{RESUMO:}

A partir do filme Truman, o show da vida o autor discute a relação entre (re)produção do espaço e vida cotidiana, buscando esclarecer as (im)possibilidades de criação numa totalidade espaço-temporal aparentemente fechada

\section{PALAVRAS-CHAVE:}

Urbanização; vida cotidiana; cinema.

\section{ABSTRACT:}

Based on the movie The Truman Show, the author discusses the relation between the (re)production of space and everyday life, searching to explain the (im)possibilities of creation in an apparently closed time-space totality.

\section{KEY-WORDS:}

Urbanization, everyday life, cinema.

"Contam-nos, não sei exatamente onde, a respeito de um Rei do Egito (Psammitichus era seu nome, creio eu) que, pensando redescobrir a origem perdida da linguagem, arranjou para criar, em um local isolado, duas crianças separadas, desde o momento do nascimento, de todo contato com o resto da humanidade. Não se conseguiu tirar, creio, nenhuma grande lição desse experimento. Uma casa de inspeção à qual tivesse se destinado um conjunto de crianças desde seu nascimento permitiria uma quantidade suficiente de experimentos que seriam bem mais interessantes." (Jeremy Bentham. O Panóptico; ou, A Casa de Inspeção)

"A miséria da vida cotidiana atinge o ápice ao pôr-se em cena na tela." (Raoul Vaneigem. $A$ arte de viver para as novas gerações)

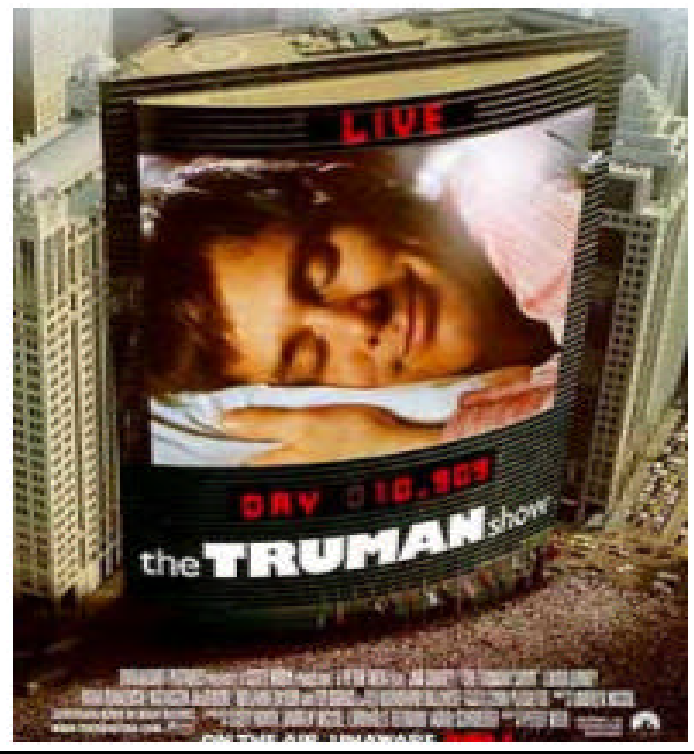

*Professor do Departamento de Geografia e do Programa de Pós-graduação em Geografia da Universidade Federal de Minas Gerais. E-mail: segiomartins@ufmg.br

** Este texto, há muito prometido para estudantes que freqüentaram minhas aulas de Geografia Urbana desde 1999, chegou a ser esboçado em 2004, quando ministrei a disciplina "A cidade, o urbano e o cinema". Por conta de inúmeras e incontroláveis circunstâncias da vida (não só acadêmica), somente o retirei da letargia em que se encontrava em janeiro de 2007 , quando alguns daqueles estudantes de graduação já concluíram seus respectivos mestrados e/ou caminham em seus doutorados. 
Truman Burbank vive placidamente seus dias em Seaheaven, uma bucólica cidadezinha encravada numa ilha homônima. Todas as manhãs, sua "conversa" consigo mesmo na frente do espelho do banheiro sobre uma hipotética exploração aventurosa é interrompida pelo chamado da esposa, lembrando-Ihe que irá se atrasar para o trabalho. $\mathrm{Na}$ cena seguinte, Truman sai de casa para pegar o carro e antes de entrar no veículo, porém, dispensa gentilmente cumprimentos convencionais aos seus vizinhos, aos da frente e ao que mora ao lado de sua bela casa. Como as demais, sua casa, com cores em tons pastéis e um jardim bem cuidado, tem cercas e portõezinhos baixos de madeira, impecavelmente pintados. As ruas, limpas, perfeitamente pavimentadas e com pouco tráfego de veículos, parecem não constituir fonte de preocupações. Talvez seja por isso que Spencer, um de seus vizinhos, deixe o cachorro correr livremente enquanto sai todas as manhãs para colocar a lata de lixo na calçada. E o dálmata Pluto adora pular em Truman para "cumprimentá-lo" antes mesmo que ele consiga entrar no carro, o que parece sobressaltálo por alguns instantes. Mas em seu rotineiro trajeto até o local de trabalho,Truman ouve pelo rádio do carro uma daquelas músicas que se costuma ouvir nas salas de espera dos consultórios. Tudo transmite tranqüilidade para que tudo transcorra sem surpresas. Poucos veículos transitam nas ruas e o fazem suavemente. Não há congestionamentos, nada de correrias.

Já no que parece ser o centro da pequena cidade, Truman, embora caminhe com alguma celeridade, ainda tem tempo para comprar o jornal para si e um exemplar de uma revista de moda para a esposa, Meryl, que trabalha no hospital da cidade como enfermeira. Cortês, não deixa de cumprimentar sorridentemente todos os que encontra, em sua maioria pessoas que, como ele, trabalham nos edifícios de escritórios ali localizados. Encontra dois senhores aos quais oferece mais uma vez uma apólice de seguros. Sim, pois Truman trabalha numa empresa de seguros. O que pode parecer um paradoxo, mas é emblemático de que se trata de um mundo onde a insegurança quanto ao presente e ao futuro foi absorvida pela administração e controle das contingências. "Lindo dia!", diz um dos senhores. "Oh, sempre!", retribui Truman. De fato, todos os dias são perfeitos em Seaheaven. Seus moradores não têm com o que se preocupar nesse idílio. A exemplo de Truman, como aparece num dos cartazes publicitários do filme, poderiam dormir tranqüilos.

Mas o cartaz prefigura aos espectadores do filme algo de que o próprio Truman, aos 30 anos de idade, ainda não sabe: que ele próprio é a parte essencial desse mundo ordenado. Obviamente, Truman o integra porque, enquanto corretor de seguros é, querendo ou não, um de seus agentes. Além disso, sua vida é também um meio para a indústria que a coloniza com seus produtos. $E$, embora não a entulhe, empanturrando-a ostensivamente com a pletora de gadgets que regurgita, faz de sua vida privada um estuário para onde convergem sem, contudo, fertilizá-la, pois sua vida é privada na mais radical acepção do termo: praticamente despojada das possibilidades de criar e estabelecer relações outras, centradas em práticas não determinadas pela e para a realização das mercadorias. Pois Truman ora é trabalhador, ora consumidor. Sua vida se consuma no âmbito de práticas que o privam de autonomia sobre ela mesma. Sobram-lhe apenas atos irrisórios nos quais a criação aparece em migalhas e como simulacro, como as brevíssimas cenas em que aparece cuidando do jardim de casa. O fundamental, porém, é que a vida de Truman Burbank é em si mesma um produto. Ele ainda não sabe disso, mas o espectador do filme, que não tem o direito de se surpreender, é logo informado do que se trata pelos primeiros créditos a surgirem no letreiro: Truman, que involuntariamente "interpreta a si próprio", foi adotado legalmente por uma empresa do setor de telecomunicações (cujo proprietário é Christof), quando era um recém-nascido órfão. O show de Truman é um programa, uma novela televisionada ininterruptamente desde então e que consiste na exibição de todos os instantes de sua vida conforme captados pelas cerca de 5 mil câmeras espalhadas por Seaheaven, um gigantesco estúdio cinematográfico em forma de abóbada (como a muralha da China, visível do espaço), onde, pressupõe-se, tudo é controlado. Truman, porém, é o único que nada sabe. Não sabe que vive rodeado de atores e a esposa, a mãe, o pai, Marlon, o amigo desde a infância, o colega 
de trabalho, o jornaleiro Earl, o motorista de ônibus; talvez até Pluto, todos desempenham papéis. Temos então a seguinte situação, que pode confundir um eventual espectador desatento: Meryl Burbank não é interpretada pela atriz Laura Linney, pois a personagem desta é Hannah Gill. E é esta que, no filme, representa a esposa de Truman no que, a rigor, é um programa televisivo. O mesmo acontece com Marlon, o melhor amigo de Truman. Quem o representa é Louis Coltrane, que é, por sua vez, o papel interpretado pelo ator Noah Emmerich.

Enfim, o filme começa no $10909^{\circ}$ dia de transmissão do show e seu enredo consiste no conflito que se prepara desde que Truman começa a ganhar consciência sobre e a partir do mundo em que vive. Isso porque, é claro, seria o fim do show, caso Truman desconfiasse de seu cárcere e resolvesse dele sair. O que torna compreensível um dos primeiros diálogos, quando, na empresa em que trabalha, Truman é informado de que precisará ir a Harbor Island fechar um negócio com um cliente. Ao jogar a desculpa esfarrapada da consulta ao dentista para se esquivar da tarefa, é prontamente advertido por Lawrence, "seu" colega de trabalho, de que perderá mais que os dentes se não cumprir sua cota, pois haverá cortes ao final do mês. Mas a ameaça de perda do emprego serve apenas para que Christof se certifique de que Truman não conseguirá vencer o medo introjetado quando criança.

De fato, Truman sequer consegue caminhar pelo píer para chegar à embarcação que supostamente o levaria para fora da ilha, porque um pequeno barco quase submerso faz voltar-lhe à tona a lembrança de que "seu" pai morrera afogado ao cair do barco no qual - levara, quando garoto, para um passeio. Esse artifício usado para assegurar a permanência de Truman nos limites da ilha constituiu um complemento incisivo aos que foram e são utilizados (com mais ou menos sutileza) para dissuadi-lo de se aventurar para além destes. Afinal, aos oito anos Truman manifestara, durante uma aula, intenções de se tornar um grande explorador, "como o grande Magalhães". "Oh, chegou tarde" respondeu decididamente a professora enquanto lhe mostrava o mapa-múndi - "não há mais nada a explorar." É por isso que no momento em que Truman, já adulto, começa a dar mostras de que cada vez menos suporta a passividade e a monotonia que se the traduzem como renúncia a explorar outros horizontes, Christof volta a instrumentalizar o medo para reforçar-lhe a resignação de viver sob o acanhamento de uma cotidianidade cristalizada na qual os mais recônditos poros de sua vida são sistematicamente ordenados e esterilizados.

Em verdade, essa constante vigília, pronta para aplacar a vontade de um quererviver outro, é significativa de que esse suposto mundo não-lacunar, esse sistema amplamente robustecido pela técnica, não é um todo coeso e rematado. Suas fissuras logo aparecem, ou, digamos assim, ele começa a fazer água logo no início do filme, senão vejamos: (i) no momento em que Truman se preparava para entrar no carro, um spot que se desprendeu do "céu" espatifou-se a poucos metros, no meio da rua; (ii) já no carro, enquanto dirige, o rádio sai de sintonia de repente e começa a captar a freqüência de comunicação utilizada pela produção do show, fazendo com que Truman seja surpreendido pela descrição minuciosa de seu trajeto, essencial para alertar aos atores que estejam em posição quando o "astro" chegar aos espaços-tempos determinados onde a cena e a encenação prosseguirão; (iii) o ator que representou Kirk, o "pai" de Truman, consegue penetrar no grande estúdio 22 anos depois da encenação de seu afogamento e, apesar de sua aparência andrajosa, é reconhecido por Truman no meio da rua, exigindo imediata atuação do elenco que, às pressas, o arrasta para fora da cena e o lança para dentro de um ônibus que sai em disparada; (iv) uma atriz, que apenas desempenharia um papel secundário, ganha dimensões não previstas porque Truman dela se enamora quando 
freqüentava o Seaheaven College. Meryl, estipulada para ser sua asséptica e insossa esposa, sai das coxias e se lança em seus braços, mas Truman jamais esquecerá Lauren Garland (interpretada pela atriz Sylvia) e seu olhar desconcertante, que lhe grita silenciosamente o que a fala não pode nem conseguirá explicar. De fato, desobedecendo o script, Sylvia quase consegue elucidar-lhe a situação em que se encontra sem saber, mas ela também é expelida da cena às pressas. E, assim, para todos os incidentes que surgem, Christof e seu staff, que não podem dormir, se esmeram em apresentar justificativas que desarmem qualquer tentativa de interrogação sobre o que acontece, sobre as escassas porosidades não preenchidas por representações formuladas fora e contra o saber que possa advir da experiência do sujeito em seu estar no mundo. Contra os fatos, versões: (i) "uma aeronave com problemas derrubou peças ao sobrevoar Seaheaven"; (ii) "desculpem, pegamos a freqüência da polícia", diz o locutor assim que a interferência de rádio cessa; (iii) "Ilha Seaheaven dá um basta nos sem-teto", é a manchete, em letras garrafais, da primeira página do jornal local, sendo essa a versão do reacionarismo sem rebuços expresso por "sua" mãe ao ouvir de Truman o relato sobre o episódio da reaparição do "pai" e sua conseqüente defenestração: "Já era hora de limparem o centro da cidade antes de ficarmos iguais ao restante do país"; (iv) "ela tem ataques de esquizofrenia", diz o suposto pai de Lauren enquanto a retira da cena no momento em que começava a dizer a Truman que é cativo numa ilha cenográfica e todos o assistem pela TV. E, para que Truman não tenha dúvidas de que jamais irá revê-la, diz que mudarão para Fiji. Desde então, a ida para Fiji (antípoda de Seaheaven, onde há ilhas "jamais visitadas pelos humanos", como diz Truman ao expor ao "amigo" Marlon suas intenções de viajar), com o intuito de reencontrar Lauren, cujo rosto tornou-se-lhe fantasmático, será, para Truman, o sentido de sua vida sem sentido.

Em meio à abundância de produtos, longe dos dramas implicados pela pobreza material, Truman vive (?) o ápice da nova miséria do homem moderno observada por Walter Benjamin nos anos 30 do século passado. "Cada manhã recebemos notícias de todo o mundo. E, no entanto, somos pobres em histórias surpreendentes. A razão é que os fatos já nos chegam acompanhados de explicações." ${ }^{1}$.

Como se sabe, embora Benjamin tenha identificado essa subtração da experiência na geração que viveu uma das mais terríveis experiências da história, entre 1914 e 1918², o homem moderno encontra-se num deserto de experiência para cuja consubstanciação uma guerra não é absolutamente necessária, já que "a pacífica existência cotidiana em uma grande cidade é, para esse fim, perfeitamente suficiente. Pois o dia-a-dia do homem contemporâneo não contém quase nada que seja ainda traduzível em experiência. [...] 0 homem moderno volta para casa à noitinha extenuado por uma mixórdia de eventos [...] entretanto, nenhum deles se tornou experiência."3. Poder-se-ia, então, dizer que Seaheaven é o protótipo do reino do inexperienciável, da experiência expropriada de seu solo original, tábula rasa na qual o acontecer é produto deliberadamente calculado, produzido e reproduzido enquanto experimento que se define num centro onde tudo é prévia e preventivamente ordenado para bloquear o saber da experiência, "que se adquire no modo como alguém vai respondendo ao que the vai acontecendo ao longo da vida e no modo como vamos dando sentido ao acontecer do que nos acontece." 4

Contudo, o insistente declínio da aura (valho-me novamente de Walter Benjamin) no mundo habitado por Truman é a centelha que instaura uma crise decisiva na sua reprodução. Pois Truman começa a perceber o que o cerca sob uma perspectiva outra, sua. Começa a perceber que os comportamentos, as atitudes, os gestos e trajetos que compõem e decompõem sua vida cotidiana a mantêm numa rotinização implacável, que não tolera o imprevisto. Começa a perceber e a se angustiar com a presença de um domínio do inautêntico 
que o protege para se precaver contra a consciência que colocaria em risco não a imutabilidade do mundo em que vive, mas o controle das mudanças que o fazem permanecer o mesmo.

Ironicamente, Truman, cujo modo de ser aurático é ressaltado por Christof aos telespectadores ("Já estamos cansados de atores com emoções falsas. [...] Truman não tem nada de falso. Não tem roteiros nem deixas. Não é sempre um Shakespeare, mas é genuíno"), vai ganhando consciência de que sua vida pouco ou nada tem de si próprio, que a lassidão e a quietude na qual sua manifesta vontade de viver é tenaz e reiteradamente confinada o tornam uma caricatura de true man. E o mais interessante é que esse fluxo de consciência não mais advém somente dos fatos que lhe devêm "de fora", de um mundo inexperienciável considerado em si mesmo. Uma descontinuidade essencial se estabelece: do eu, cuja consciência fundava-se na coleção de sensações - as "falhas técnicas" que casualmente Ihe propiciaram outras sensações, perturbaram a consciência anteriormente produzida, ela também atada à imediaticidade do real, mas até então considerado por sua inexorabilidade -, ao sujeito que infere, a partir do sensível, sobre o mundo e seu lugar nele. O ser, antes considerado em si, agora é para o conhecer, que se torna atividade. Truman começará a conhecer a realidade ao dela se apropriar como ser prático, começando assim a transpor o abismo que separava ser e conhecer.

De fato, Truman começa a observar fatos, situações, comportamentos... Observa o que se passa e os que passam. Aqui, pessoas mais ou menos apressadas. Acolá, fragmentos de uma conversa na praça da "cidade". No meio dessas simulações de práticas urbanas, descobre indícios, reúne evidências, constata padrões do mesmo em sua infindável repetição: repara que uma mulher numa bicicleta, depois um homem carregando flores e, por fim, um fusca com pára-choque amassado dão voltas, repetida e indefinidamente, em frente à casa em que mora. Identifica circularidades que o aprisionam às linearidades de um eterno presente, a uma infernal correspondência entre a forma espacial semi-esférica de Seaheaven e as práticas consubstanciadas por movimentos que o imobilizam num tempo vivido como sucessão espacializada de instantes inanes. É desse labiríntico espaço-tempo anti-histórico, desse materialismo destituído de dialética que Truman tentará escapar.

E, num primeiro momento, o fará de modo imediato, sem mediações outras além da recusa aberta, da vontade prática de escapar da violência intrínseca às práticas que o humilham por reduzi-lo à condição de objeto ${ }^{5}$. Começa fazendo entrar nessa vida nadificada, impossível de se viver, a espontaneidade desestabilizadora. Meryl, que inadvertidamente entrara no carro no qual Truman fazia suas observações, fica bastante surpresa e muitíssimo assustada quando, após trancar as portas, Truman Ihe diz que sairiam de Seaheaven naquele momento e, sem demora, subitamente arranca com o carro. "Para onde vamos?", pergunta. "Não sei. Estou sendo espontâneo", responde Truman enquanto dirige velozmente. E ainda acrescenta: "Vamos esquecer Fiji."

Não deixa de ser interessante observar o recurso a esse esquematismo da indústria cultural. Sabemos que, repetido ad nauseam, adestra o espectador a associar liberdade à possibilidade de se deslocar mecanicamente à velocidade permitida pela potência do motor sob uma reluzente carcaça metálica sobre rodas (talvez não seja mero acaso que Truman possua um Ford ${ }^{6}$ ). Entretanto, mesmo essa liberdade exteriorizada, transferida para uma coisa ${ }^{7}$, pobremente reduzida ao poder conferido pela posse desse objeto arquetípico da vida moderna, se mostra ameaçadora, pois num lapso de tempo Truman detém o controle das situações. Como detêla? Demonstrando sua impotência. Neutralizando-a ao Ihe opor o congestionamento paralisante! Ora, mas Seaheaven é representada como um paraíso (imutavelmente) perfeito (cujo eloqüente epitáfio A nice place to live - consta na placa do carro do próprio Truman). Portanto, o inferno do engarrafamento imobilizador que multiplica o tempo imposto ${ }^{8}$ é percebido como extraordinário, como contradição concreta que irrompe no ordinário da utopia abstrata de uma realidade urbana supostamente sem contradições, inerte, coagulada, sem História. Então, Truman, que já 
sabe que o imprevisto só acontece por acidente, nele não se detém. Dá meia volta e pega a estrada para sair da "cidade".

Poderíamos considerar que esses atos larvares dos experimentos que Truman começa a fazer não passam de contestação fragmentária. Decerto, não mais orientados pela busca da figura fantasmática de Lauren-Fiji, tais atos não visam um centro, cuja existência Truman ignora. Porém, não consistem apenas na fuga anárquica (na acepção dos gregos da Antigüidade clássica: ausência de arkhé, do que é princípio e fundamento das ações e/ou do que Ihes dá sentido e orientação) que, após algumas peripécias, é freada. Não se trata de um alucinado em fúria que busca se desvencilhar de um presente desprezível porque dele não brotará nenhum amanhã. Não se pode dizer que se trata de atos desatados de uma totalidade, pois esta começa a ser tangida. Mesmo embebidos em certo desaviso, tais experimentos permitem a Truman enfrentar o medo que o agrilhoava (consegue atravessar uma ponte sobre a água ao fechar os olhos enquanto acelerara o carro obrigando Meryl a dirigi-lo), ao mesmo tempo em que Ihe propicia novas experiências, como as evidências de que é policiado mesmo quando os que o cercam (literalmente) se mostram polidos (não por acaso, um "policial", ao Ihe explicar os supostos motivos do bloqueio da estrada, involuntariamente o chama pelo nome). Na medida, portanto, em que começa a reconhecer que não pode contar com ninguém, pois cada um é agente do todo, a totalidade é percebida não por sua abertura em direção a um viveroutro, mas por seu fechamento, pelo controle total, ou melhor, totalitário.

Não é demais lembrar que dentre as características fundamentais do totalitarismo, conforme sublinhadas por Hannah Arendt em seu célebre estudo, encontra-se a decretação da superfluidade do humano em sua essencialidade, em seu vir a ser. Em síntese apertada, dizia a filósofa que somente nos campos de concentração, nesses laboratórios que constituem a verdadeira instituição central do poder organizacional totalitário, é possível o experimento do domínio total, posto que este visa a abolição da liberdade e até mesmo a eliminação de toda espontaneidade humana, e não a simples restrição, por mais tirânica que seja, da Herdade. Nessa perspectiva podese compreender melhor o significado de Truman consistir num objeto, numa propriedade da empresa de Christof desde quando era um bebê, pois

"quando uma criança nasce, um outro aparece entre nós. E é um outro porque [...] uma criança é algo absolutamente novo que dissolve a solidez do nosso mundo e que suspende a certeza que nós temos de nós próprios. Não é o começo de um processo mais ou menos antecipável, mas uma origem absoluta, um verdadeiro início. Não é o momento em que colocamos a criança numa relação de continuidade conosco e com nosso mundo (para que se converta em um de nós e se introduza em nosso mundo), mas o instante da absoluta descontinuidade, da possibilidade enigmática de que algo que não sabemos e que não nos pertence inaugure um novo início." 10

A infância, essa presença de algo radical e irredutivelmente outro, enigmática porque escapa às representações que buscam fixá-la para a despojar de sua força inaugural, ao mesmo tempo em que inquieta o "pensamento" que busca apagar as diferenças e se esmera em ocultar as contradições para bloquear toda tentativa de interrogação das indeterminações do real ${ }^{11}$, exige, por conseguinte, que 0 pensamento se ponha em movimento para compreendê-la, que se abra para ir ao encontro de sua verdade ${ }^{12}$ (restituindo assim, acrescento, a dialética).

"Na medida em que encarna o surgimento da alteridade, a infância nunca é o que sabemos (é o outro dos nossos saberes), mas, por outro lado, é portadora de uma verdade à qual devemos nos colocar à disposição de escutar; nunca é aquilo apreendido pelo nosso poder (é o outro que não pode ser submetido), mas ao mesmo tempo 
requer nossa iniciativa; nunca está no lugar que a ela reservamos (é o outro que não pode ser abarcado), mas devemos abrir um lugar para recebê-la. Isso é a experiência da criança como um outro: o encontro de uma verdade que não aceita a medida do nosso saber, com uma demanda de iniciativa que não aceita a medida do nosso poder, e com uma exigência de hospitalidade que não aceita a medida de nossa casa. A experiência da criança como um outro é a atenção à presença enigmática da infância, a esses seres estranhos dos quais nada se sabe e a esses seres selvagens que não entendem nossa língua." ${ }^{\prime 3}$

Se considerarmos (ainda com Larrosa) que a educação é o "modo como as pessoas, as instituições e as sociedades respondem à chegada daqueles que nascem", o que exige "abrir-se à interpelação de uma chamada e aceitar uma responsabilidade, [...] abrir um espaço em que aquele que vem possa habitar; pôr-se à disposição daquele que vem, sem pretender reduzi-lo à lógica que impera em nossa casa"14 , que significa, então, a definição da infância como "o objeto de estudo de um conjunto de saberes mais ou menos científicos, a coisa apreendida por um conjunto de ações mais ou menos tecnicamente controladas e eficazes [...]"15 ? Que significa a infância reduzida "a algo que, de antemão, já sabemos o que é, o que quer ou do que necessita"? Se ao invés de nos abrirmos a esses "seres estranhos dos quais nada se sabe" para os encontrarmos em sua verdade, os defrontamos como "se conhecêssemos, de antemão, o resultado desse processo de individualização e de socialização através do qual as crianças converter-se-ão em pessoas como nós mesmos", atribuindo à educação a tarefa de realizar a infância convertida em "matéria prima para a realização de nossos projetos sobre o mundo, de nossas previsões, nossos desejos e nossas expectativas sobre o futuro"16,

"Deveríamos nos perguntar, então, até que ponto toda educação, entendida como a realização de um projeto, reduz a novidade da infância no sentido em que a reconduz às condições existentes e a faz dedutível daquilo que já existia. Deveríamos nos perguntar, em suma, pelo alcance dessa frase célebre e provocadora que escreveu o heterônimo de Antonio Machado, Juan de Mairena: 'houve um pedagogo: chamava-se Herodes'."17

Poderíamos então considerar que Christof (e seu nome é, portanto, emblemático) é um Herodes de nosso tempo, personificando o totalitarismo de hoje? Decerto. Mas não apenas por ter convertido o enigma daquele que nasce em um meio para produzir um futuro previsto de antemão. Do alto da sala lunar, no $221^{\circ}$ andar da ecosfera OmniCam, o centro privado onde se define a decisão, Christof ostenta suas insígnias: é o comandante da corporação que detém o monopólio do modo de aparecer do real, do ser redutível ao aparecer. O terrorismo encarnado por ele é o de uma sociedade que pretende não ter mais história que a do acúmulo de suas técnicas acachapantes. O que não significa que prescinda da violência desabrida, sem rebuços, mantida em estado latente, como se verá.

Reatando com a seqüência do filme de Peter Weir: apesar de seus comandados terem conseguido deter Truman em suas primeiras investidas contra o mundo que lhe é claramente hostil e amedrontador, parecendo assim restabelecer o curso dos acontecimentos regulados pelo perpétuo presente sem futuro, Christof sabe que os arranhões ao seu suposto sistema ameaçam gangrená-lo. Percebe que esse excesso de paliação a que se viu obrigado a fazer indica que algo não previsto no mundo sublunar começa a lhe escapar. Então, sai da defensiva e, para restaurar o controle total, tenta uma espécie de cura pelo veneno. Traz o pai de Truman (cujo corpo, obviamente, jamais fora encontrado) de volta à cena. É "o toque de gênio" do "criador e arquiteto do mundo dentro de um mundo", enfatiza o servil apresentador de um programa televisivo ao qual Christof (zeloso de sua privacidade, como é dito) concede uma entrevista depois dos momentos de turbulência. "Já que Kirk iniciou essa crise na vida de Truman, concluí que ele era o único que poderia acabar com ela.". E, de fato, depois do esforço para obstruir as diversas tentativas de Truman de sair das circularidades de um mundo dado por toda eternidade, parece que as forças da ordem finalmente conseguiram amarrálo ao pelourinho do tempo sem História.

Mas Christof obteve uma vitória de Pirro. Seu alívio é prematuro, pois a aparente resignação de 
Truman ao insuportável presente tedioso escondia algo que preparara no insondável dos subterrâneos. Literalmente, pois justamente enquanto se encontrava no porão de sua casa, em momentos e atos aparentemente irrisórios e desimportantes, Truman conseguiu escapar desapercebido das câmeras.

Ao constatar a fuga de Truman, Christof mobiliza todos os profissionais (atores, técnicos, diretores) a seu serviço, que vasculham a cidade-cenário como um exército de autômatos auxiliados pela intensa luz fria projetada a partir da "lua" onde está sediado. Como não o encontram, o próprio Christof, depois de ordenar a "alvorada" em plena madrugada, dirige sua iluminação totalitária aonde Truman jamais ousou ir. É no mar, tal qual um "grande navegador", que Truman é encontrado.

Contraditoriamente, a epopéia claustrofóbica de Truman, que é francamente não prevista e, portanto, não controlada, retira o show do ritmo morno da reprodução nauseante da mesmice ordinária. Contradição que é prontamente capitalizada por Christof, pois apesar de advertido sobre a iminente morte de Truman diante das câmeras (já que ordenara a revolta do mar para deter sua fuga), Christof não se comove, haja vista a explosão dos índices de audiência. Os fãs de Truman ficam grudados na TV torcendo para que ele se liberte, de certo modo, deles mesmos, pois muitos deles são consumidores vorazes dos produtos vendidos durante o show (tudo está à venda no catálogo Truman: "desde a roupa dos atores, a comida e até as casas em que moram"18).

Poder-se-ia dizer que o filme, esse produto da indústria cinematográfica, escorrega, utilizando amplamente os surrados jargões hollywoodianos que antecipam aos espectadores o seu final, não Ihes exigindo nenhum esforço intelectual, como observavam dois críticos frankfurtianos ${ }^{19}$. Todos aguardam pela "heroificação do indivíduo mediano" (no caso, um típico estadunidense de classe média) que consegue escapar do cotidiano pasteurizado, libertar-se da tirania do diretortitereiro, dos holofotes que nada deixam nas sombras. Todos são recompensados com o final catártico do desenrolar previsível da seqüência maniqueísta: Truman sai da tempestade e encontra a finitude do mundo no qual vivera ao romper com o seu barco o paredão com o céu pintado em fundo infinito.

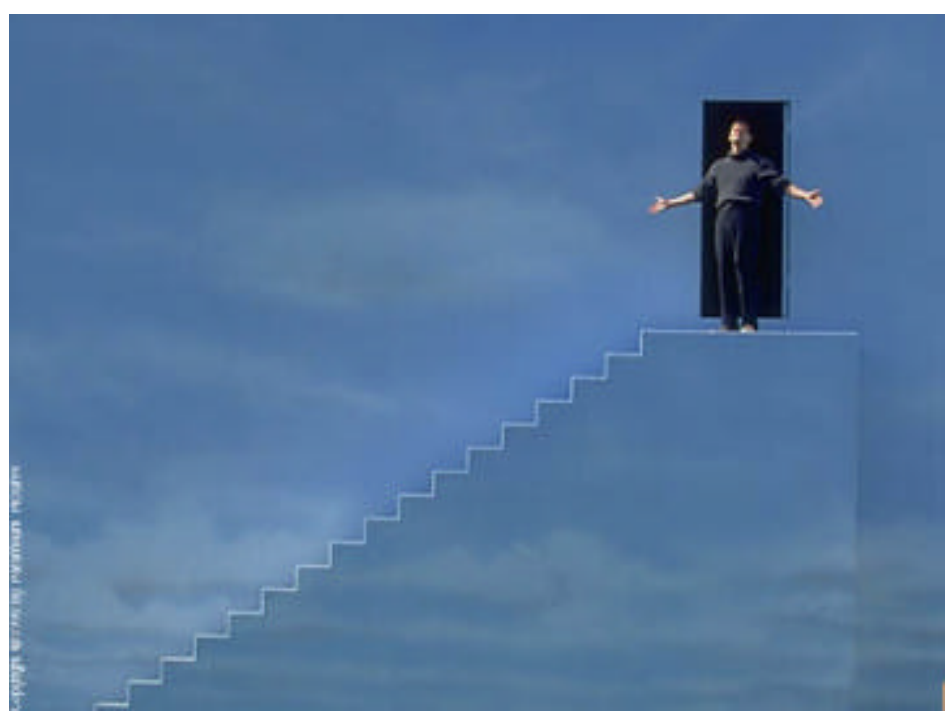


Sobe as escadas que o levam à porta que dá acesso àquilo que corresponderia ao mundo real em oposição à pura artificialidade de Seaheaven. E finalmente a transpõe, depois de um breve diálogo com Christof que, numa última tentativa de demovê-lo, reverbera do alto do firmamento desanuviado, considerações sobre a verdade do mundo por ele produzido.

Não obstante, a questão a reter, ao meu ver, não é exatamente se Peter Weir teria amesquinhado seu filme adequando-o aos esquematismos da indústria que aparentemente criticava. Tampouco se se trata de um confinamento de um indivíduo em uma ilha de artificialidade (a exemplo da "cidade" concebida por W. Disney, como citado anteriormente) coalhada de tecnologia em oposição ao mundo real do qual fora apartado desde sempre, pois não se trata de uma dicotomia entre um mundo real e um irreal. Afinal, Seaheaven é uma límpida expressão da realidade urbana produzida no âmbito de uma sociedade crescentemente orientada pelos termos da reprodução capitalista da riqueza ${ }^{21}$. Um espaçotempo regido e controlado tecnocraticamente, implicando numa deterioração da vida social correspondente ao "caráter desértico" das práticas espaciais consentidas e estimuladas. Se considerarmos que a urbanização é intrínseca ao homem, que em sua trajetória de humanização ele cria e recria diferentes formas do urbano, como as cidades, a realidade urbana produzida e reproduzida tal como Seaheaven é a negação do humano, a exponenciação da alienação do homem em relação às suas obras, nas e pelas quais realiza sua natureza. Enquanto produtos, enquanto mercadorias, suas obras lhe escapam, voltam-se contra ele, tornam-se estranhas e ameaçadoras. Não obstante, o filme nos instiga a refletir sobre a atividade de conhecimento do mundo, a atitude filosófica, a desfetichização que questiona o já dado, a verdade supostamente absoluta do real apresentado em si mesmo.

$\mathrm{Na}$ trajetória de Truman pode-se reconhecer momentos da atitude filosófica, que tem seu ponto de partida justamente no espanto (celebremente expressa no "Sei que nada sei" socrático), que compreende o início da sabedoria ${ }^{20}$. Esta não é um estado, mas um processo, um convite à procura da verdade sempre provisória que, por isso, não nega o pensamento. No filme, a mais óbvia citação a esse processo é a de que se trata de um itinerário (a própria educação) que permite ao sujeito sair do domínio das sombras ao qual se encontrava acorrentado, ascendendo das representações turvas do plano sensível em direção à luz do plano inteligível, tal qual a fabulação platônica da caverna ${ }^{21}$.

De maneira não tão óbvia, porém, há ainda no filme a alusão ao mito da criação do mundo sensível (domínio do devir, do que é instável e perecível porque sujeito a mudanças) pela mediação de um demiurgo, conforme o relato cosmológico platônico do $\mathrm{Timeu}^{22}$. O demiurgo de que fala Platão é a inteligência ordenadora do mundo sensível com base no mundo inteligível (reino das Idéias, do Sumo Bem, do que é estável e belo). Contemplando e imitando o mundo das Idéias, que toma como modelo, cria o Cosmos operando como um artesão que utiliza várias técnicas. Em sua atividade teórica e prática, o demiurgo imprime representações do mundo inteligível no espaço.

"O Bem cria um demiurgo (demiourgós), isto é, um artesão sumamente inteligente, matemático e arquiteto, bom e sem mácula, que irá criar o mundo sensível para difundir e multiplicar o Bem. Que faz o demiurgo? Como arkhitektón, contempla as idéias, as toma como modelos ou paradigma e as copia, imprimindo-as na matéria perecível e mutável, a khorá, receptáculo informe e desordenado. A impressão das formas puras e eternas na matéria bruta, informe e perecível, dá origem ao kósmos, que, imitação do mundo inteligível, possui, como este, uma alma inteligente que o governa, a Alma do Mundo. O mundo é concebido, assim, como um objeto técnico, um artefato submetido a regras, leis e planos - por isso é um cosmo - e também como um todo animado ou um grande animal, um ser vivo. A relação entre o mundo sensível e o mundo inteligível é a da imitação ou mímesis, isto é, a relação entre um modelo e sua cópia."23

Poderíamos dizer, então, que Seaheaven consiste no domínio da mimésis, realização prática 
e teórica da filosofia, ao qual Truman estaria acorrentado? Não! Primeiro, porque entre os antigos (até Platão sobretudo) a mimésis não se destacava da poiésis ${ }^{24}$. Não se restringia, portanto, à pura e simples repetição. $E$, em segundo lugar, porque esta, a repetição, consiste no limite inferior da mimésis, para o qual tende a ser reduzida no mundo moderno. O fundamental a considerar (de acordo com as observações de Henri Lefebvre ao traçar os limites de uma teoria geral da mimésis) é não só a distinção entre mimésis e noções como a repetição e a imitação ${ }^{25}$, mas sobretudo a restituição do conceito ao situá-lo como modalidade da praxis. O que, obviamente, significa que tal teoria pressupõe uma análise da práxis ${ }^{26}$. E é justamente a esse ponto que é preciso voltar, para afirmar (mesmo que em linguagem platônica) que o mundo sensível não é uma cópia imperfeita de uma essência transcendente.

"O mundo da realidade não é uma variante secularizada do paraíso, de um estado já realizado e fora do tempo; é um processo no curso do qual a humanidade e o indivíduo realizam a própria verdade, operam a humanização do homem. [...] o mundo da realidade é o mundo da realização da verdade, é o mundo em que a verdade não é dada e predestinada, não está pronta e acabada, impressa de forma imutável na consciência humana: é o mundo em que a verdade devém. Por esta razão a história humana pode ser o processo da verdade e a história da verdade. [...] significa que a verdade não é nem inatingível, nem alcançável de uma vez para sempre, mas que ela se faz; logo, se desenvolve e se realiza." 27

Se é certo que o homem só conhece o real na medida em que dele se apropria submetendo-o à própria práxis, portanto criando-o e recriando-o, poderíamos encerrar com as seguintes expressões socráticas que bem poderiam constar acima da porta transposta por Truman ao sair de Seaheaven para, a partir de então, começar a conhecer mais e melhor o mundo no qual se produz um modo de vida crescentemente fechado à criação, no qual o homem é crescentemente cindido de sua natureza ao ser impedido justamente de ser humano: "Conhece-te a ti mesmo" e "torna-te o que és"!

\section{Notas}

${ }^{1}$ BENJAMIN, Walter. Magia e técnica, arte e política: ensaios sobre literatura e história da cultura. $7^{a}$ ed. São Paulo: Brasiliense, 1994, p.203.

A partir das observações benjaminianas, Jorge Larrosa discerniu com precisão a experiência da informação: "A experiência é o que nos passa, o que nos acontece, o que nos toca. Não o que se passa, não o que acontece ou o que toca. A cada dia se passam muitas coisas, porém, ao mesmo tempo, quase nada nos acontece. Dir-se-ia que tudo o que se passa está organizado para que nada nos aconteça. [...] Nunca se passaram tantas coisas, mas a experiência é cada vez mais rara. Em primeiro lugar pelo excesso de informação. A informação não é experiência. E mais, a informação não deixa lugar para a experiência, ela é quase o contrário da experiência, quase uma antiexperiência. Por isso a ênfase contemporânea na informação, em estar informados, e toda a retórica destinada a constituir-nos como sujeitos informantes e informados; a informação não faz outra coisa que cancelar nossas possibilidades de experiência. O sujeito da informação sabe muitas coisas, passa seu tempo buscando informação, o que mais o preocupa é não ter bastante informação [...] porém, com essa obsessão pela informação [...] o que consegue é que nada lhe aconteça." LARROSA, Jorge Bondía. Notas sobre a experiência e o saber de experiência. Revista Brasileira de Educação, São Paulo, n.19, p. 2028, jan-abr. 2002. p.21-22.

2 "Na época, já se podia notar que os combatentes tinham voltado silenciosos do campo de batalha. Mais pobres em experiências comunicáveis, e não mais ricos. Os livros de guerra que inundaram o mercado literário nos dez anos seguintes não continham experiências transmissíveis de boca em boca. [...] Uma nova forma de miséria surgiu com esse monstruoso desenvolvimento da técnica, sobrepondo-se ao homem." BENJAMIN, Walter. Ibid. p.114-115.

${ }^{3}$ AGAMBEN, Giorgio. Infância e história: destruição da experiência e origem da História. Belo 
Horizonte: Editora UFMG, [1978] 2005, p.21-22.

${ }^{4}$ LARROSA, Jorge Bondía. Ibid. p.27.

5 Marilena Chauí demonstrou limpidamente que "A violência se opõe à ética por que trata seres racionais e sensíveis, dotados de linguagem e de liberdade como se fossem coisas, isto é, irracionais, insensíveis, mudos, inertes ou passivos. Na medida em que a ética é inseparável da figura do sujeito racional, voluntário, livre e responsável, tratá-lo como se fosse desprovido de razão, vontade, liberdade e responsabilidade é tratá-lo não como humano e sim como coisa [...]" CHAUÍ, Marilena. Ética e violência. In: COLÓQUIO INTERLOCUÇÕES COM MARILENA CHAUÍ. 1998, Londrina. mar. 1998/São Paulo. abr. 1998, p. 2.

O "sentimento de humilhação", correspondente ao "sentimento de ser objeto", foi destacado por Raoul Vaneigem em $A$ arte de viver para as novas gerações. São Paulo: Conrad Editora, [1967] 2002, p.39.

6 Dentre a vasta bibliografia sobre o fordismo não apenas como reestruturação dos processos produtivos, mas também e sobretudo como padrão de acumulação do capital (aí incluídas as implicações políticas do compromisso fordista do operariado), destaco, além dos trabalhos dos economistas da chamada escola da regulação, BRAVERMAN, Harry. Trabalho e capital monopolista: a degradação do trabalho no século XX. 3aed. Rio de Janeiro: Zahar, [1974] 1981. esp. parte I, cap.6; HARVEY, David. A condição pós-moderna: uma pesquisa sobre as origens da mudança cultural. São Paulo: Edições Loyola, [1989] 1992. esp. parte II e BIHR, Alain. Da grande noite à alternativa: o movimento operário europeu em crise. $2^{a}$ ed. São Paulo: Boitempo Editorial, [1991] 1999. esp. parte I. Sobre o automóvel, considerado para além de um objeto técnico: LUDD, Ned (org.). Apocalipse motorizado: a tirania do automóvel em um planeta poluído. São Paulo: Conrad, 2004 e LEFEBVRE, Henri. A vida cotidiana no mundo moderno. São Paulo: Ática, [1968] 1991. esp. p.110-115.

7 Cf. MARX, Karl. Manuscritos económico-filosóficos. Trad. Artur Mourão. Lisboa, Edições 70, (1844) 1975.

8 "Classificando-se as horas (do dia, da semana, do mês, do ano) em três categorias, a saber: o tempo obrigatório (o do trabalho profissional), o tempo livre (o dos lazeres), o tempo imposto (o das exigências diversas fora do trabalho, como transporte, idas e vindas, formalidades etc.), verifica-se que o tempo imposto ganha terreno. [...] O tempo imposto se inscreve na cotidianidade e tende a definir o cotidiano pela soma das imposições (pelo conjunto delas)." LEFEBVRE, Henri. Obra citada, p.61. Cf., do mesmo autor, De lo rural a lo urbano (antologia preparada por Mario Gaviria). Barcelona: Ediciones Península, [1970] 1978. esp. cap. XII (Necesidades profundas, necesidades nuevas de la civilización urbana).

9 Em seu magistral estudo sobre o stalinismo, e especialmente sobre o nazismo, Hannah Arendt caracterizou o totalitarismo nos seguintes termos: "Nas condições do regime totalitário, a categoria dos suspeitos compreende toda a população; todo pensamento que se desvia da linha oficialmente prescrita e permanentemente mutável já é suspeito, não importa o campo de atividade humana em que ocorra. Simplesmente em virtude de sua capacidade de pensar, os seres humanos são suspeitos por definição, e essa suspeita não pode ser evitada pela conduta exemplar, pois a capacidade humana de pensar é também a capacidade de mudar de idéia. [...] O domínio total, que procura sistematizar a infinitude da pluralidade e diferenciação dos seres humanos como se toda a humanidade fosse apenas um indivíduo, só é possível quando toda e qualquer pessoa seja reduzida à mesma identidade de reações. [...] Quem aspira ao domínio total deve liquidar no homem toda a espontaneidade, produto da existência da individualidade, e persegui-la em suas formas mais peculiares, por mais apocalípticas e inocentes que sejam. O cão de Pavlov, o espécime humano reduzido às reações mais elementares, o feixe de relações que sempre pode ser liquidado e substituído por outros feixes de relações de comportamento exatamente igual, é o 'cidadão' modelo do Estado totalitário; e esse cidadão não pode ser produzido de maneira perfeita a não ser nos campos de concentração. [...] O totalitarismo não procura o domínio despótico dos homens, mas sim um sistema em que os homens sejam supérfluos. O poder total só pode ser conseguido e conservado 
num mundo de reflexos condicionados, de marionetes sem o mais leve traço de espontaneidade. Exatamente porque os recursos do homem são tão grandes, só se pode dominálo inteiramente quando ele se torna um exemplar da espécie animal humana." ARENDT, Hannah. Origens do totalitarismo: anti-semitismo, imperialismo, totalitarismo. São Paulo: Companhia das Letras, [1950] 1989. p.481-508.

10 LARROSA, Jorge. Pedagogia profana: danças, piruetas e mascaradas. $4^{\mathrm{a} e d .}$ Belo Horizonte: Autêntica, [1998] 2004, p.187.

${ }^{11}$ Estas são características atribuídas à ideologia por Marilena Chauí. Cf. CHAUÍ, Marilena. Cultura e democracia: o discurso competente e outras falas. 7aed. São Paulo: Cortez, [1989] 1997, p.3-13.

12 "[...] a verdade não é a representação fidedigna de uma realidade coisificada, mas é a instauração do real no próprio acontecimento de sua aparição. [...] a verdade nunca é subordinação do que aparece a nossos conceitos, a nossas idéias ou a nossos saberes, mas que é assombro diante do que permanece simultaneamente descoberto e escondido. A verdade da infância não está no que dizemos dela, mas no que ela nos diz no próprio acontecimento de sua aparição entre nós, como algo novo." LARROSA, Jorge. Pedagogia profana, p.195.

13 Ibid., p.186.

${ }^{14}$ Ibid., p.188, ênfases do autor.

15 Ibid., p. 184.

${ }^{16}$ Ibid., p. 188.

17 Ibid., p. 190.

18 É oportuno lembrar Celebration, a "cidade Disney", na Flórida: "O desenvolvimento meticulosamente planejado chega completo, com paliçadas, uma associação de proprietários nomeados pela Disney e uma torre de água falsa. [...] a vida que o Camundongo está oferecendo talvez não seja aquela que esperávamos dele. Quando Walt Disney concebeu uma cidade de grife, ela significava uma mina de artificialidade, um templo aos deuses futuristas de meados dos anos 50, os deuses da tecnologia e da automação. A cidade nunca foi construída enquanto Walt estava vivo, embora algumas de suas idéias tenham ido para o Epcot Center 16 anos depois de sua morte. Quando decidiu retomar o velho sonho de Walt e construir uma cidade de marca, o CEO da Disney, Michael Eisner, optou por não criar o mundo de fantasia inspirado nos Jetsons que seu predecessor havia imaginado. Embora seja equipada com toda tecnologia e conveniência modernas, Celebration é menos futurismo que uma homenagem, uma recriação idealizada da América afável que existia antes dos shoppings, megalojas, vias expressas, parques de diversão e comercialização em massa. O estranho é que Celebration não é tanto um veículo de vendas para produtos licenciados de Mickey Mouse; é, em termos contemporâneos, quase uma cidade sem a Disney - sem dúvida a única que restou na América. Em outras palavras, quando a Disney finalmente conquistou seu espaço totalmente cercado, sinergizado e auto-suficiente, escolheu criar um mundo pré-disneyficado - sua estética serena e atenuada é a antítese do mundo da animação que encontramos à venda no Disney World [...]." (KLEIN, Naomi. Sem logo: a tirania das marcas em um planeta vendido. $2^{a}$ ed. Rio de Janeiro: Record, [2000] 2002, p.179).

19 Cf. ADORNO, Theodor W. e HORKHEIMER, Max. Dialética do esclarecimento: fragmentos filosóficos. Rio de Janeiro: Jorge Zahar Ed., [1944] 1985, esp. p.113-156.

${ }^{20}$ Cf. HELLER, Agnes. A filosofia radical. São Paulo: Brasiliense, 1983.

21 "Agora, meu caro Glauco, é preciso aplicar, ponto por ponto, esta imagem ao que dissemos atrás e comparar o mundo que nos cerca com a vida da prisão na caverna, e a luz do fogo que a ilumina com a força do Sol. Quanto à subida à região superior e à contemplação dos seus objetos, se a considerares como a ascensão da alma para a mansão inteligível, não te enganarás quanto à minha idéia, visto que também tu desejas conhecê-la. [...] A educação é, pois, a arte que se propõe este objetivo, a conversão da alma, e que procura os meios mais fáceis e mais eficazes de o conseguir. Não consiste em dar visão ao órgão da alma, visto que já a tem; mas, como ele está mal orientado e não olha para onde deveria, ela esforça-se por encaminhá-lo na boa direção." PLATÃO. A república. São Paulo: Nova Cultural, 1997, livro VII, p.228-229. 
22 Cf. PLATON. Timée-Critias. Trad. Luc Brisson. 4 éd. Paris: Flammarion, 1999.

${ }^{23}$ CHAUÍ, Marilena. Introdução à filosofia: dos présocráticos a Aristóteles. v.1. $2^{a}$ ed. rev. e ampl. São Paulo: Companhia das Letras, 2002, p.269. É importante observar que a criação do mundo pelo demiurgo não é uma criação ex nihilo. "[...] Em primeiro lugar, o modelo que utiliza não é de sua criação e nem poderia sê-lo, porque esse modelo é eterno; igualmente, o receptáculo, a 'matéria' que 'recebe' as imagens das formas inteligíveis, o Demiurgo já a encontra existindo; e, finalmente, sua ação é limitada pela necessidade." BITAR, Hildeberto. Apresentação. In: PLATÃO. Diálogos. v. XI (Timeu - Crítias - O $2^{\circ}$ Alcibíades - Hípias Menor). Trad. Carlos Alberto Nunes. Belém: Universidade Federal do Pará, 1977, p.15. O demiurgo platônico não é, portanto, onipotente, como também não o é Christof. Para compreendê-lo, basta utilizar uma formulação moderna (marxiana): Christof é, antes de mais nada, um capitalista e, portanto, está a serviço da reprodução do capital. O ímpeto da acumulação é o senhor de sua consciência, fazendo com que sua vida esteja a seu serviço. Move-se, portanto, dentro de configurações que não criou mas de cuja reprodução é agente, vivendo num mundo enfeitiçado cujas relações afiguram-se-lhe como atributos das coisas.

24 "A mimèsis reproduzia o ato criador, o da fundação (real ou suposta). [...] Dessa história primitiva, na qual se misturaram mimèsis e poièsis, para logo se distinguirem (em têrmos de ciências parcelares, a cosmogonia, a religião, a tecnologia não se diferenciavam ainda), Platão conservounos os sinais. [...] Platão define admiràvelmente, chamando-a metexis (participação), a mimèsis original tal como a concebemos: com duplo aspecto, voltado, de um lado, para um termo inacessível que se esforça por apreender e incorporar (encarnando-o em obra sensível) - e, de outro, para o que se repete e foge para a desordem, o caótico e o informe. É, pois, mediação, participação que não copia à maneira do ceramista quando reproduz um vaso posto diante dêle, fora dele. É uma participação ativa e criadora, malgrado a observação contestável de Aristóteles no livro II da Metafísica (v.987 B 1113) que opõe a metexis (platônica) à mimèsis (pitagórica). [...] A mimèsis aristotélica torna-se atividade literária, função psicológica e discursiva: a imitação. [...] $\mathrm{Na}$ antigüidade, são precisos séculos para que a cisão se realize. [...] A mimèsis segue a poièsis, mas dela se destaca lentamente. A poièsis caracteriza-se pela unidade primordial dos elementos que se dissociaram: tecnicidade, imagem do mundo, ação sôbre as coisas e sôbre o grupo, presença do povo, decisão dos chefes, solenidade. Propicia um compromisso gestual - isto é, vivido em certa prática - entre o rito e a exigência técnica, entre o poder misterioso atribuído às decisões fundadoras e a real habilidade, ela mesma dupla, referente às coisas e aos homens. [...] A mitologia antiga nos oferece admirável exemplo de poièsis espontânea, de criação inicial e primordial, em si mesma 'inconsciente', seguida de uma mimèsis ela própria viva, criadora, refletindo e prolongando a poièsis da qual derivava." LEFEBVRE, Henri. Metafilosofia. Rio de Janeiro: Civilização Brasileira, [1965] 1967. p.272-281.

25 "Nossa crítica da mimèsis, crítica fundamental e radical, exige que seu conceito seja plenamente restituído ou constituído. Não pode reduzir-se à imitação tal como o expusemos aqui; a mimèsis é ativa." Ibid. p.295-296.

26 "Não apresentamos senão um modo entre outros de analisar a praxis, ligando-a a uma determinação primordial, a poièsis e mostrando em seguida como ela se destaca (incompletamente) enquanto mimèsis." Ibid. p.297.

27 KOSÍK, Karel. Dialética do concreto. Trad. Célia Neves e Alderico Toríbio. $5^{a}$ ed. Rio de Janeiro: Paz e Terra, [1963] 1989, p.18-19, ênfases do autor. 
